\title{
Ocorrência de Phytophthora nicotianae em mamoneira (Ricinus communis L.) no Brasil
}

\author{
Haroldo Antunes Chagas ${ }^{1 *}$, Ana Carolina Firmino ${ }^{1}$, César Junior Bueno ${ }^{2}$; Marcos Vinícius Oliveira dos Santos ${ }^{3}$, Edna \\ Dora Martins Newman Luz ${ }^{3}$; Edson Luiz Furtado ${ }^{1} \&$ Maurício Dutra Zanotto ${ }^{4}$
}

${ }^{1}$ Faculdade de Ciências Agronômicas da UNESP, Departamento de Produção Vegetal/Defesa Fitossanitária. Rua José Barbosa de Barros, n. 1780, Cxa. Postal 237, CEP 18610-307, Botucatu-São Paulo; ${ }^{2}$ Centro Experimental Central do Instituto Biológico/APTA. Rodovia Heitor Penteado, Km 3, Jd. das Palmeiras, CEP 13092-543, Campinas - São Paulo; ${ }^{3}$ Seção de Fitopatologia, Centro de Pesquisas do Cacau, Comissão Executiva do Plano da Lavoura Cacaueira, Cxa. Postal 07, CEP 45600-970, Itabuna, Bahia. ${ }^{4}$ Faculdade de Ciências Agronômicas da UNESP, Departamento de Produção Vegetal/Agricultura. Rua José Barbosa de Barros, n. 1780, Cxa. Postal 237, CEP 18610-307, Botucatu-São Paulo.

Autor para correspondência: Haroldo Antunes Chagas (haroldo.antunes2099@gmail.com)

Data de chegada: 26/09/2012. Aceito para publicação em: 28/04/2013

$10.1590 / 0100-5405 / 2037$

A cultura da mamoneira (Ricinus communis L.), apesar de sua rusticidade, pode sofrer ação de diversos fitopatógenos, implicando em perda de produtividade. Fusarium oxysporum f. sp. ricini é o único fungo de solo que ocorre na cultura [Massola Junior, N. S. \& Bedendo, I. P. Doenças da mamoneira. In: Kimati, H. et al. (Eds.). Manual de fitopatologia: doenças das plantas cultivadas. 4 ed. São Paulo: Agronômica Ceres, 2005. v.2: p. 445-447].

Isolou-se de mudas de mamoneira (cv. IAC 80) plantadas diretamente em amostras de solo coletadas em 2010 em uma Fazenda produtora de mamoneira, localizada no município Santa Rita do Oeste / São Paulo - Brasil, no meio de cultura ágar-água, apenas um isolado do oomiceto Phytophthora sp. Como não há relato deste patógeno na cultura, o objetivo do presente trabalho foi relatar e identificar a espécie de Phytophthora que ocorre na mamoneira. Em copos plásticos descartáveis contendo solo autoclavado, plântulas de mamoneira cv. IAC 80 com 10 dias de germinação foram inoculadas com o isolado de Phythophthora sp. na região do colo pelo método do palito de madeira colonizado com o fungo (Trionfetti-Nisini et al. Screening for resistance to Didymellabryoniae in rootstocks of melon. Bulletin-OEPP, v. 30, n. 2, p. 231-234, 2000). Após 24 horas de câmara úmida, todas as plântulas inoculadas apresentaram a região do colo e suas raízes totalmente enegrecidas e as folhas encontravam-se murchas, diferindo das plântulas do tratamento testemunha que se encontravam sadias (Figura 1). A sintomatologia do teste de patogenicidade foi idêntica a que ocorreu nas plântulas de onde foi obtido o isolado. Após o re-isolamento do patógeno das plântulas inoculadas, o isolado de Phytophthora sp. foi considerado o agente causal de murcha e necrose de colo e raiz na mamoneira IAC 80 (Figura 1).

Após isso, o isolado de Phytophthora foi enviado para a Comissão Executiva do Plano da Lavoura Cacaueira, Centro de Pesquisas do
Cacau (CEPLAC/CEPEC), localizado no município Itabuna, no Estado da Bahia, visando a sua identificação. O isolado foi colocado para crescer no meio de cultura cenoura-agar (CA), em estufa BOD a $25 \pm 1{ }^{\circ} \mathrm{C}$, sob luz constante, e aos sete dias de crescimento, o mesmo apresentou colônias em forma de estrela, com micélio aéreo ligeiramente floculoso e raros esporângios. Discos $(0,7 \mathrm{~cm}$ de diâmetro) destas culturas em CA foram transferidos para placas de Petri $(5 \mathrm{~cm}$ de diâmetro) contendo $8 \mathrm{~mL}$ de água estéril e, após $72 \mathrm{~h}$, sob as mesmas condições de temperatura e luminosidade, observou-se a formação de esporângios sobre o disco de cultura e ao redor do mesmo. Os esporângios, formados em esporangióforos com ramificação simpodial irregular, foram predominantemente ovoides, mas vários quase esféricos e raros elipsoides, não-caducos e papilados, as vezes com duas papilas, medindo $37(19,3-49,0)$ x 28,6(15,8-32,5) $\mu \mathrm{m}$ (média de 50 esporângios), relação comprimento/largura 1.3:1. As papilas mediram $6,2(2,3-8,8) \mu \mathrm{m}$ de profundidade e $6,4(3,5-8.8) \mu \mathrm{m}$ para abertura do poro apical (Figura 1). Clamidósporos terminais e intercalares sempre presentes, com diâmetro médio para 50 unidades avaliadas de 22,9(14,9$31,5) \mu \mathrm{m}$. O isolado quando cultivado em CA a temperatura de $35^{\circ} \mathrm{C}$ apresentou crescimento micelial durante os sete dias de cultivo. Folhas de plântulas de fumo, 30 dias após semeadura foram inoculadas, sem ferimento, colocando-se discos de cultura de CA com estruturas do patógeno sobre a superfície das folhas e mantidas em câmara úmida por $48 \mathrm{~h}$. Quando as lesões começaram a aparecer, isto demonstrou que o isolado foi patogênico às folhas de fumo (Nicotiana tabacum L.) (Figura 1). Crescimento a $35^{\circ} \mathrm{C}$ e patogenicidade às folhas de fumo diferenciam P. nicotianae de outras espécies de Phytophthora morfologicamente similares. Correndo chaves taxonômicas de espécies de Phytophthora, as medidas dos esporângios e clamidósporos do isolado de mamoneira enquadram-se dentro dos limites do táxon da espécie $P$. nicotianae
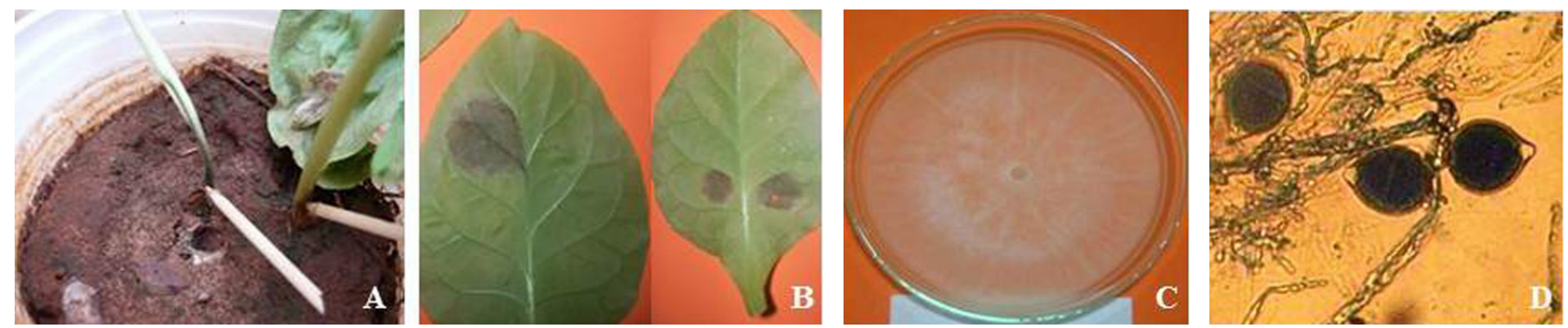

Figura 1. A) Teste de patogenicidade - Detalhe do colo necrosado e murcha das plântulas de mamoneira; B) Manchas necróticas em folhas de fumo (Nicotiana tabacum L.) inoculadas com discos de culturas do isolado de Phytophthora nicotianae obtido de plântulas de mamoneira; C e D - Isolado de P. nicotianae de mamoneira; C) Cultura em cenoura-ágar, aos 7 dias de cultivo; D) Esporângios (aumento de 400 x). 
(Waterhouse, G.M. Key to the species of Phytophthora de Bary. Kew Commonwealth Mycological Institute. Mycological Papers, v. 92, 1963. 22 p.; Gallegly, M.E. Hong, C.X. Phytophthora: identifying species by morphology and DNA fingerprints. St. Paul, Minessota: APS Press. 2008, 158 p.). Visando ainda a sua correta identificação, a região ITS-5.8S rDNA do isolado foi sequenciada e essa apresentou 99\% de similaridade com sequência de um isolado de P. nicotianae (GU983639) do GENBANK-NCBI, corroborando os dados obtidos pela caracterização cultural e morfológica.

No Brasil há relato de $P$. nicotianae ocorrendo em guaraná
(Paullinia cupana D.), em maracujazeiro (Passiflora sp.) (Kimati, H.; Amorim, L.; Bergamin Filho, A.; Camargo, L.E.A.; Rezende, J.A.M. Manual de Fitopatologia: Doenças das Plantas Cultivadas. 3 ed. São Paulo: Agronômica Ceres, 1997. v. 2, 774 p.) e em diversos outros hospedeiros (Luz, E.D.M.N.; Matsuoka, K. Phytophthora: Fungo protista ou Chromista? In: Luz, E.D.M.N.: Santos, A.F. dos; Matsuoka, K.; Bezerra, J.L. (Ed.). Doenças causadas por Phytophthora no Brasil. Campinas: Livraria Editora Rural. 2001. p. 1-22). Porém, este é o primeiro relato no Brasil de P. nicotianae causando podridão escura no colo e raízes seguido de murcha em plântula de mamoneira. 